\title{
Dynamics of commercial real estate market segments in the post-pandemic period
}

\author{
Oksana Pirogova, ${ }^{1 *}$, and Vilena Zasenko ${ }^{1}$ \\ ${ }^{1}$ Peter the Great St. Petersburg Polytechnic University, 195251, 29 Polytechnicheskaya str., St. \\ Petersburg, Russia
}

\begin{abstract}
Research background: Commercial real estate segments have reacted differently to the effects of the coronavirus pandemic, announced early last year. Thus, the greatest interest is represented by commercial, service and warehouse real estate. The retail segment seriously felt the restrictions in the work of retail and service enterprises from March to July 2020 - due to the rotation of operators, the departure of many players from the market, the vacancy rate of space increased, the average rental rate decreased due to the revision of lease agreements. Warehouse real estate, on the contrary, has received incentives for development due to a twofold increase in online trade in Russia - the vacancy rate in the most high-quality areas tends to $0-2 \%$, the average rental rate is growing rapidly.

Purpose of the article: to analyze the commercial real estate market in the context of retail and warehouse real estate in the regions of Russia and St. Petersburg, to develop mechanisms to increase their competitiveness in the postcovid period.

Methods: description, comparison, analogy, generalization and correlation and regression analysis.

Findings \& Value added: there is a high dependence of the current state of retail and warehouse real estate on the growing volumes of online trade, which causes certain trends: the growth of the shortage of warehouse space and the increase in the vacancy rate of retail space-mechanisms have been developed to increase the competitiveness of commercial real estate operators in St. Petersburg and the regions
\end{abstract}

Keywords: warehouse real estate market, retail real estate market, competitiveness, postcovid period

JEL Classification: $L 85, O 18, O 44$

\footnotetext{
*Corresponding author: kafedra17@rambler.ru
} 


\section{Introduction}

At the current stage, commercial real estate is faced with an unprecedented set of macroeconomic factors affecting the dynamics of commercial real estate development, such as the coronavirus pandemic announced by WHO in early 2020, and the subsequent restrictions on the operation of trade and service enterprises, an unstable situation with prices for Russia's main export commodity - oil, the dynamics of the exchange rate of the national currency, affecting the general dynamics of the development of commercial real estate, the main purpose of which is to generate profit from operating activities (Pirogova et al., 2019). Of all segments of commercial real estate, according to consulting companies, warehouse real estate has suffered the least, which has become the main driver of growth in recent years due to the development of Internet commerce (moreover, in 2020, there was a twofold increase in turnover attributable to online sales) and offline retailers business scaling (Plotnikov and Pirogova, 2018). During the year, the retail real estate segment was negatively affected by work restrictions; the vacancy rate in 2020 increased compared to previous years because tenants were not physically able to fulfill their obligations (Yoshida, 2020; Skribans, et al., 2020).

In this regard, the relevance of forecasting the commercial real estate market is increasing in order to identify "pain points" that stop growth, and possible drivers that would allow the objects of retail and warehouse real estate to acquire competitive advantages. Purpose of the study: to propose ways to increase the competitiveness of commercial real estate on the basis of forecasting the dynamics of the development of the retail and warehouse real estate market in the regions of Russia.

\section{Materials and Methods}

Commercial real estate in Russia began to form only with the beginning of the privatization of enterprises. The commercial real estate sector is less capacious than the residential one, therefore there are correspondingly fewer transactions, although commercial real estate is the most attractive all over the world (Ardolino et al., 2018).

Commercial real estate can be subdivided into income-generating - commercial real estate itself and creating conditions for its extraction - industrial real estate (Martín-Peña et al., 2019; Bakarich et al., 2019). Table 1 shows the comparative characteristics of the commercial real estate segments.

Table 1. Comparative characteristics of commercial real estate segments

\begin{tabular}{|l|l|l|}
\hline \multicolumn{1}{|c|}{ Criteria } & \multicolumn{1}{|c|}{ Trade and service } & \multicolumn{1}{c|}{ Industrial } \\
\hline Object type & $\begin{array}{l}\text { Shops, shopping centers, roadside } \\
\text { service facilities, catering facilities, } \\
\text { free premises }\end{array}$ & $\begin{array}{l}\text { Industrial buildings, } \\
\text { warehouses, industrial plants }\end{array}$ \\
\hline $\begin{array}{l}\text { The level of rental rates, } \\
\text { rubles / sq.m / year in } \\
\text { the regions of Russia }\end{array}$ & \multicolumn{1}{|c|}{$\sim 35000-70000$} & $\sim 3060-4200$ \\
\hline Vacancy rate, \% (2020) & \multicolumn{1}{|c|}{$5-6 \%$} & \multicolumn{1}{c|}{$3.4 \%$} \\
\hline Classification & $\begin{array}{l}\text {-Typology of the chief analyst of the } \\
\text { RGr G.M. Sternik; } \\
\text {-Classification of the Urban Land } \\
\text { Institute; } \\
\text {-Classification by the International } \\
\text { Council of Shopping Centers; } \\
\text {-Classification of the Russian Council } \\
\text { of Shopping Centers (RCSC) }\end{array}$ & $\begin{array}{l}\text {-Classification developed by } \\
\text { the international consulting } \\
\text { company Knight Frank }\end{array}$ \\
- SanPiN & $\begin{array}{l}\text {-Classification developed by } \\
\text { the consulting company } \\
\text { Swiss Realty Group }\end{array}$ \\
\hline Standards & TC: \\
\hline
\end{tabular}




\begin{tabular}{|l|l|l|}
\hline & $\begin{array}{l}\text { - t air not less than } 5 \text { gr. higher than } \\
\text { outside during the cold season; } \\
\text { - floors made of moisture-proof } \\
\text { materials with a flat surface; } \\
\text { - finishing materials approved by } \\
\text { health authorities }\end{array}$ & $\begin{array}{l}\text { - optimal } \mathrm{t}-14-25 \mathrm{C}, \text { in the } \\
\text { warm season should not } \\
\text { exceed the outside by more } \\
\text { than } 5 \mathrm{C} ; \\
\text { - air humidity - } 60-70 \% ; \\
\text { - the presence of places for } \\
\text { collecting waste, industrial } \\
\text { waste, other garbage. }\end{array}$ \\
\hline Main trends & $\begin{array}{l}\text { The growing influence of online } \\
\text { trading and the adaptation of offline } \\
\text { operators to new changes, the } \\
\text { development of omnichannel }\end{array}$ & $\begin{array}{l}\text { The warehouse real estate } \\
\text { market is growing - } \\
\text { including due to the } \\
\text { development of e-commerce, } \\
\text { expansion of the network of } \\
\text { grocery retailers }\end{array}$ \\
\hline
\end{tabular}

\section{Results and Discussion}

Let us analyze the dynamics of the development of commercial real estate segments: retail and warehouse.

Commercial real estate segments have responded in different ways to the impact of the coronavirus pandemic (Pirogova et al., 2020). Thus, the pandemic had the most negative impact on retail real estate (Salisu et al., 2020). The restrictions on the operation of shopping centers introduced by the Government during 2020 led to a significant increase in vacant space, a decrease in the average rental rate due to the revision of lease agreements, rotation of operators.

Today, cities with a population of 100 to 300 thousand people have the greatest potential for the construction of retail real estate, which are characterized by a shortage of high-quality supply of retail facilities and a relatively high level of income of the population (Li et al., 2020). These cities include the second or third largest cities after the administrative centers, as well as cities located in the North and the Far East (Liu et al., 2020). Since 2019, there has been interest in them from developers (by the end of 2021, their share should reach $25 \%$ of the total volume, by 2019 - no more than 15\%). The dynamics of average rental rates for retail space and the level of vacancy are shown in Figure 1.

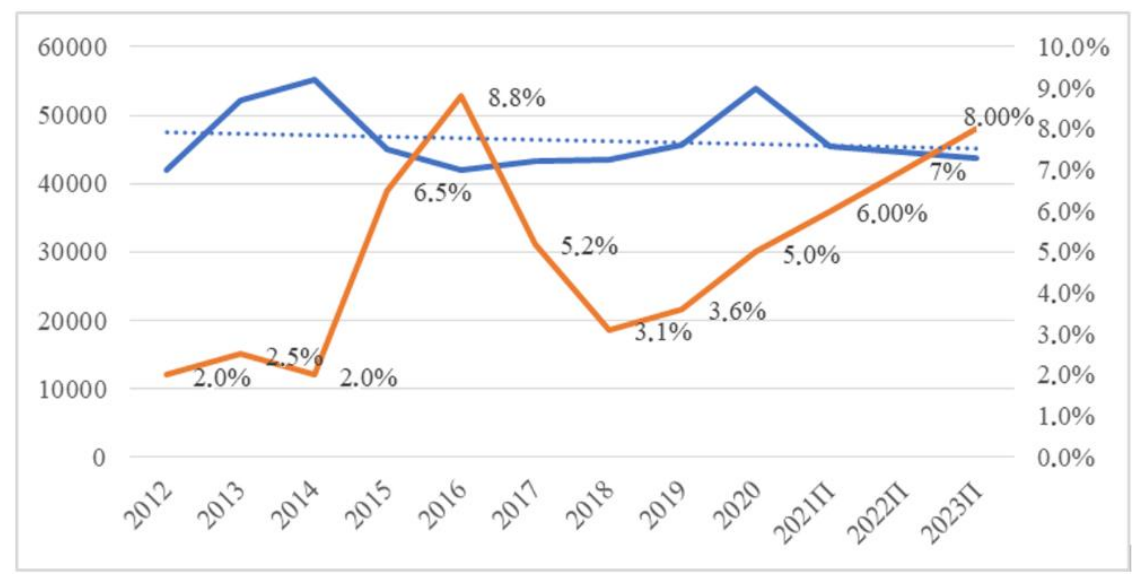

Figure 1. Dynamics of rental rates (rubles / $\mathrm{m}^{2} /$ year) and vacancy rate $(\%)$.

The diagram shows that since 2018 there has been an increase in the vacancy rate of retail space (the level of 2020 is $2.9 \%$ more than in 2018). The dynamics of rental rates, given the high sensitivity of the trading sector to changes in macroeconomic indicators, shows an 
increase in values in 2014 and 2020, when the world and national economies were experiencing crisis phenomena (Carmichael and Coën, 2020). No obvious dependence of rental rates on the level of vacancy was found (Kowalkowski et al., 2017).

The restrictions have affected the attendance of shopping centers in the regions. Attendance in regional shopping centers after the reopening recovered in different ways, depending on the current restrictions (in several regions, restrictions were reintroduced), the level of income of the population and the availability of a high-quality supply of retail space (Volkova et al., 2021). High traffic and sales rates persisted in modern shopping malls located in large cities, shoppers were slower to return to malls in low-income cities, as well as in cities where there is still a shortage of retail space (Bykova, 2021).

Consumer demand, met by classic shopping malls, has shifted to the online environment during the pandemic (Bykowa et al., 2020). The e-commerce market, which added about 10$20 \%$ annually in growth rates, grew by $58.5 \%$ in 2020 , according to AK\&T. At the same time, the domestic trade market added $92 \%$ in 2020 compared to 2019 . The dynamics of the growth of the presence of Internet commerce in Russia are presented in Figure 2.

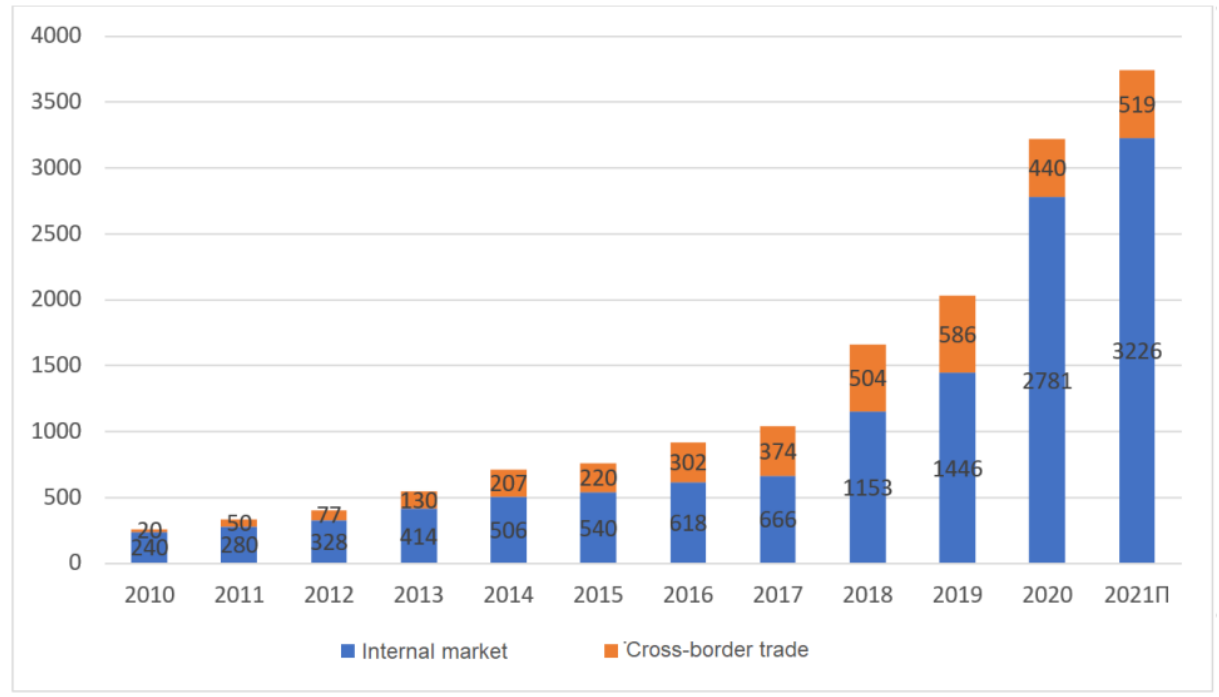

Figure 2. Russian Internet trade market (billion rubles).

The dynamics of the Russian e-commerce market indicates a significant increase in the turnover of the online sphere, and in 2020 we see a $25 \%$ decrease in the share of cross-border trade. This is due to the difficult epidemiological situation in the world, a decrease in the total volume of international trade, and restrictions on cross-border travel (Vertakova, et al., 2016).

The significant growth of the domestic market was due to several reasons, including the development of domestic online trading platforms (marketplaces), for example OZON, Wildberries, YandexMarket, etc., an increase in the number of high-speed Internet users, the development of a logistics network of retail operators, time constraints due COVID-19, the growth of the market for delivery services (Ruščáková, 2015).

Average rental rates for high-quality warehouses in key regional cities are shown in Figure 3. 


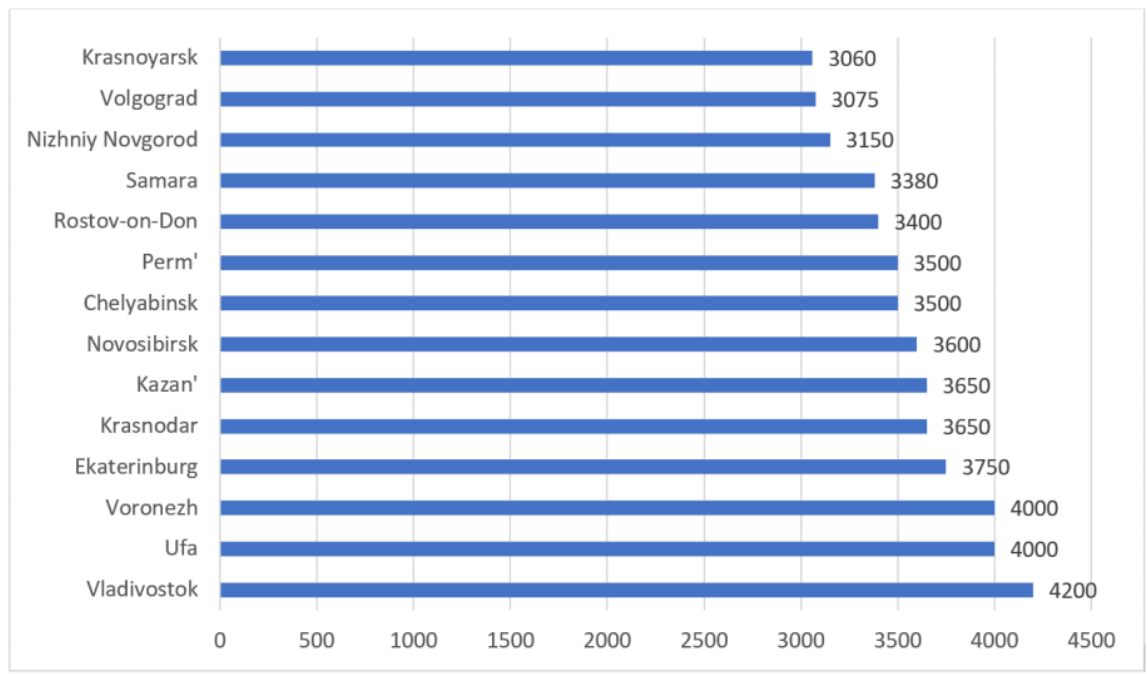

Figure 3. Average rental rates for high-quality warehouses in Russian cities (rubles / sq.m / year)

The dynamics of the vacancy rate of warehouse space in the regions of Russia is shown in Figure 4.

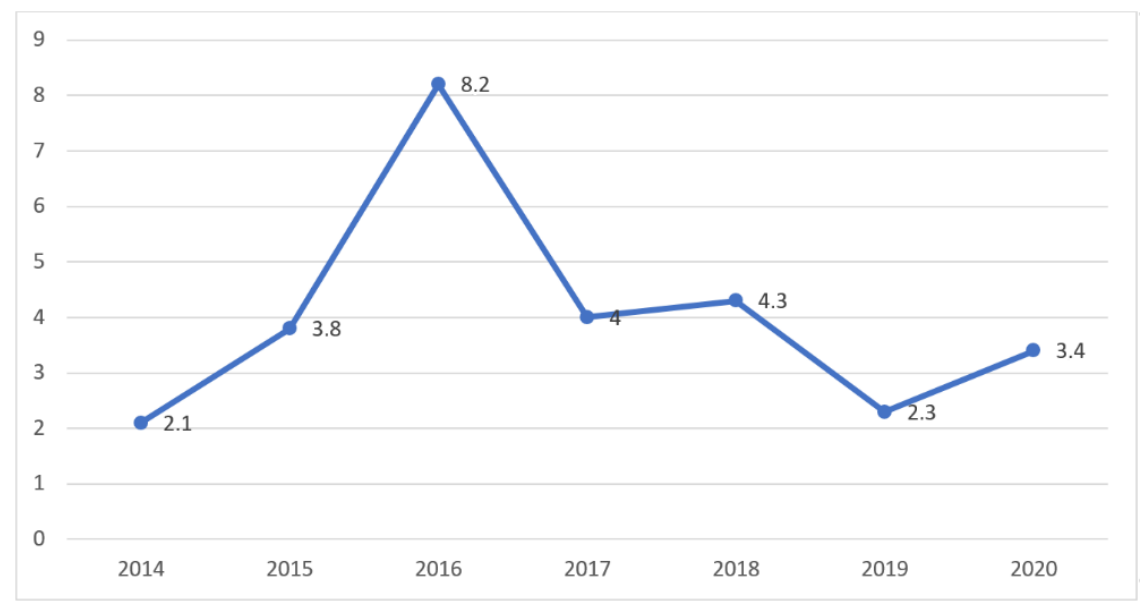

Figure 4. Dynamics of the vacancy rate in the regions of Russia (\%)

The dynamics of the vacancy rate shows a decrease since 2016, at the end of 2020 it was $3.4 \%$, which is 1.1 percentage points higher than in 2019 . The increase was caused by the significant commissioning of new areas in the regions (Nishibe, 2015).

The main purpose of this study is to find competitive advantages for commercial real estate by predicting the dynamics of development of retail and warehouse real estate in the face of growing volumes of e-commerce (Fernandez and Aalbers, 2016).

For the correlation-regression analysis, we selected primary data on the volumes of Internet trade in Russia, as well as retrospective data on rental rates for retail and warehouse real estate in St. Petersburg. The choice of data on rental rates for St. Petersburg commercial real estate is justified by the following: the heterogeneity of the commercial real estate market in the Russian regions; the inability to determine the average rental rate for the entire set of regions; the proximity of the St. Petersburg commercial real estate market to the markets of large administrative centers of the Russian regions. 
Table 2. Input data for analysis

\begin{tabular}{|c|c|c|c|c|}
\hline \multirow[b]{2}{*}{ Period } & \multicolumn{2}{|c|}{ Retail real estate } & \multicolumn{2}{|c|}{ Warehouse real estate } \\
\hline & $\begin{array}{c}\text { Rent rate, rubles / } \\
\mathbf{m}^{2} / \text { year } \\
(\mathbf{y})\end{array}$ & $\begin{array}{c}\text { Volume of e- } \\
\text { turnover, RUB } \\
\text { billion (RF), } \\
(\mathbf{x})\end{array}$ & $\begin{array}{l}\text { Rent rate, } \\
\text { rubles } / \mathbf{m}^{2} / \\
\text { year } \\
(y)\end{array}$ & $\begin{array}{c}\text { Volume of e- } \\
\text { turnover, RUB } \\
\text { billion (RF), } \\
\text { (x) }\end{array}$ \\
\hline 1H 2016 & 4000 & 405 & 4100 & 405 \\
\hline $2 \mathrm{H} 2016$ & 3800 & 515 & 4100 & 515 \\
\hline $1 \mathrm{H} 2017$ & 3600 & 498 & 3900 & 498 \\
\hline $2 \mathrm{H} 2017$ & 3500 & 542 & 3900 & 542 \\
\hline $1 \mathrm{H} 2018$ & 3800 & 575 & 3600 & 575 \\
\hline 2H 2018 & 3800 & 675 & 3600 & 675 \\
\hline $1 \mathrm{H} 2019$ & 3850 & 725 & 3900 & 725 \\
\hline $2 \mathrm{H} 2019$ & 3900 & 895 & 3960 & 895 \\
\hline $1 \mathrm{H} 2020$ & 4100 & 1570 & 4100 & 1570 \\
\hline $2 \mathrm{H} 2020$ & 4300 & 1567 & 4200 & 1567 \\
\hline \multicolumn{5}{|c|}{ Forecast } \\
\hline $1 \mathrm{H} 2021$ & 4277 & 1800 & 4155 & 1800 \\
\hline $2 \mathrm{H} 2021$ & 4298 & 1850 & 4165 & 1850 \\
\hline $1 \mathrm{H} 2022$ & 4400 & 2100 & 4220 & 2100 \\
\hline $2 \mathrm{H} 2022$ & 4483 & 2300 & 4260 & 2300 \\
\hline $1 \mathrm{H} 2023$ & 4565 & 2500 & 4300 & 2500 \\
\hline $2 \mathrm{H} 2023$ & 4935 & 3400 & 4500 & 3400 \\
\hline 1H 2024 & 4976 & 3500 & 4520 & 3500 \\
\hline $2 \mathrm{H} 2024$ & 5058 & 3700 & 4560 & 3700 \\
\hline
\end{tabular}

Source: Pirogova et al. (2019); Ardolino et al. (2019).

The results of the correlation analysis are presented in Table 3.

Table 3. Results of correlation analysis.

\begin{tabular}{|l|c|}
\hline \multicolumn{1}{|c|}{ Segment } & Correlation coefficient \\
\hline Retail real estate & 0.972955 \\
\hline Warehouse real estate & 0.875417 \\
\hline
\end{tabular}

The results obtained $(0.973$ and 0.87$)$ show a high level of correlation between the rental rates for warehouse and retail real estate and the volume of e-commerce.

Regression analysis was carried out using the data from Table 2. To build the model, the resulting indicator equation was used:

$$
\mathrm{y}=\mathrm{b}_{0}+\mathrm{b}_{1}{ }^{*} \mathrm{x}_{1}
$$

where,

$\mathrm{y}$ - resulting indicator (rental rate of warehouse / retail real estate, rubles / sq. m / year);

$\mathrm{b}_{0}, \mathrm{~b}_{1}$ - regression coefficients;

$\mathrm{x}_{1}$ - factor that determines the resulting indicator (volume of e-turnover, billion rubles).

The results of the regression analysis performed graphically are presented in Figures 5 and 6. 


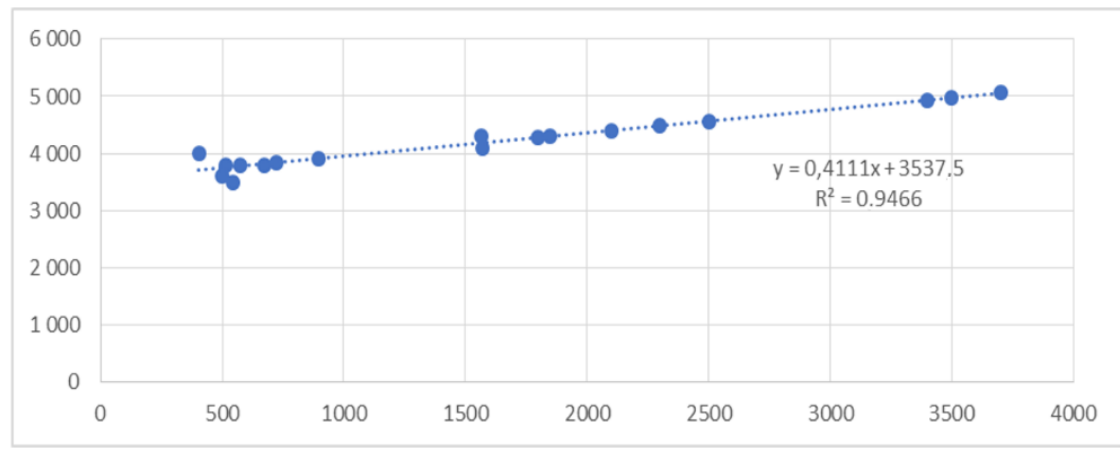

Figure 5. Regression model of the influence of e-commerce volumes on the rental rate of retail real estate, 2016-24

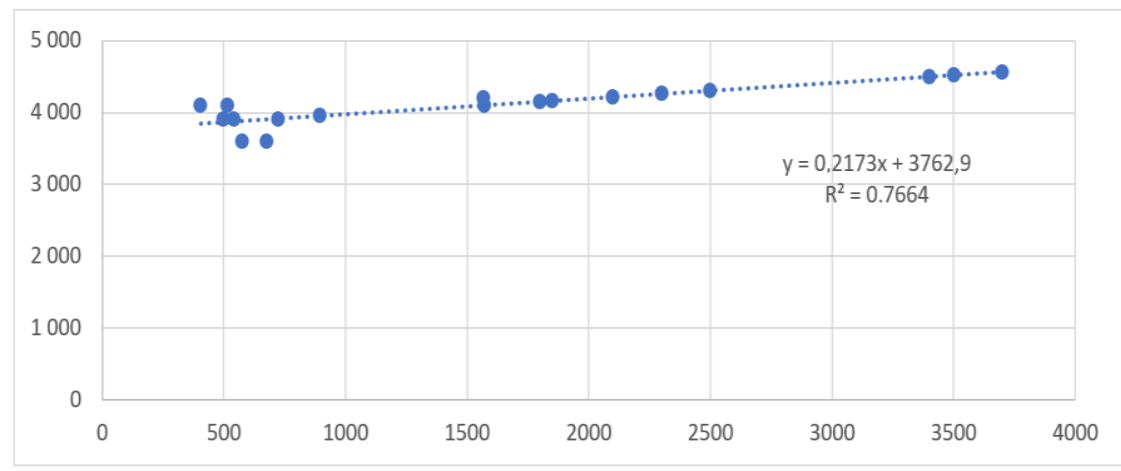

Figure 6. Regression model of the influence of e-commerce volumes on the rental rate in St. Petersburg, 2016-24

The regression analysis performed graphically showed that the models of the influence of factors (volume of e-commerce) on the resulting indicator (rental rates) make sense. Equation of the resulting indicator obtained from rental rates for commercial real estate:

$$
y=0.4111 x+3537.5
$$

where $\mathrm{R}^{2}=0.9466$.

Equation of the resulting indicator obtained from rental rates in St. Petersburg:

$$
y=0.2173 x+3762.9
$$

were $\mathrm{R}^{2}=0.7664$

Based on the data obtained during the correlation-regression analysis, we conclude that commercial real estate (in this study - retail and warehouse) is largely subject to changes in the growth rate of online trade in Russia. That is, with an increase in the volume of online trade turnover, the average rental rate for commercial space will increase. Moreover, retail real estate is more sensitive to changes due to the homogeneity of the market.

The results of the correlation-regression analysis made it possible to reveal a strong relationship between the state of the retail and warehouse real estate market and the dynamics of the development of online trading, respectively, in the coming years online trading will be a challenge for one and a driver for another.

Thus, it is possible to identify pain points of both markets and propose ways to solve them, to increase competitiveness in a pandemic and post-pandemic time.

Table 4 provides a summary of the challenges and ways to overcome them in order to gain a competitive advantage. 
Table 4. Increasing the competitiveness of commercial real estate objects

\begin{tabular}{|c|c|c|c|}
\hline Segment & Problem & $\begin{array}{c}\text { Probability } \\
\text { of occurrence }\end{array}$ & Solution \\
\hline \multirow{3}{*}{ Retail } & $\begin{array}{l}\text { Increasing the } \\
\text { level of vacancy } \\
\text { of premises }\end{array}$ & High & $\begin{array}{l}\text { - a decrease in the rate of commissioning } \\
\text { of new areas; } \\
\text { - improvement of commercial conditions } \\
\text { for tenants }\end{array}$ \\
\hline & $\begin{array}{l}\text { Reduced rental } \\
\text { rates }\end{array}$ & Average & $\begin{array}{l}\text { - redevelopment of obsolete areas; } \\
\text { - optimization of retail spaces }\end{array}$ \\
\hline & $\begin{array}{l}\text { Decline in } \\
\text { consumer demand }\end{array}$ & Average & $\begin{array}{l}\text { - space optimization - improvement of } \\
\text { online order issuing zones; } \\
\text { - development of omnichannel }\end{array}$ \\
\hline \multirow{3}{*}{ Warehouse } & $\begin{array}{l}\text { Increasing the } \\
\text { vacancy rate }\end{array}$ & Average & $\begin{array}{l}\text { - redevelopment of warehouse facilities; } \\
\text { - automation of logistics operations; } \\
\text { - development in built-to-suit format }\end{array}$ \\
\hline & Space shortage & High & $\begin{array}{l}\text { - redevelopment of obsolete objects; } \\
\text { - an increase in the rate of entry }\end{array}$ \\
\hline & $\begin{array}{l}\text { Reduced rental } \\
\text { rates }\end{array}$ & Low & $\begin{array}{l}\text { - ensuring the optimal level of } \\
\text { construction of speculative objects }\end{array}$ \\
\hline
\end{tabular}

Source: Bykova (2021); Bykowa et al. (2020); Vertakova and Plotnikov (2016); Ruščáková (2015); Nishibe (2015); Fernandez and Aalbers (2016)

The ways to increase the competitiveness of commercial real estate listed in Table 4 will reduce the negative impact of negative trends that have arisen on the commercial real estate market.

\section{Conclusion}

Research results:

- analyzed the theoretical aspects of the functioning of commercial real estate in Russia (considered segments of commercial real estate, brief statistical data on the current state of retail and warehouse real estate; lists the standards and classification currently used in Russia);

- the current state of retail and warehouse real estate in Russian regions was analyzed, the degree of influence of the coronavirus pandemic, trends and development forecasts for the post-pandemic time were determined (it was determined that the segment most affected by the consequences of the pandemic was the retail segment, however, the warehouse market, on the contrary, received additional incentives for growth for due to the increased demand for space from online retailers);

- a correlation and regression analysis of the influence of the growth of Internet trade volumes on the development of both segments was carried out - a high relationship was revealed between the factors "volume of the e-commerce market" and "rental rate of commercial real estate", which is one of the main indicators of the current state of the industry;

- based on retrospective data on rental rates and forecasted volumes of Internet trade in Russia, a forecast of the dynamics of the cost of renting the retail and warehouse segment until 2024 was built;

- on the basis of the predicted dynamics, the ways of increasing the competitiveness of services provided by the objects of the trade and warehouse segment were proposed. 


\section{References}

1. Ardolino, M., Rapaccini, M., Saccani, N., Gaiardelli, P., Crespi, G., \& Ruggeri, C. (2018). The role of digital technologies for the service transformation of industrial companies. International Journal of Production Research, 56(6), 2116-2132.

2. Bakarich, K.M., Hossain, M., \& Weintrop, J. (2019). Different time, different tone: Company life cycle. Journal of Contemporary Accounting and Economics, 15(1), 6986.

3. Bykova, E. N. (2021). Assessment of negative infrastructural externalities when determining the land value. Journal of Mining Institute, 247(1), 154-170.

4. Bykowa, E., Hełdak, M., \& Sishchuk, J. (2020). Cadastral land value modelling based on zoning by prestige: A case study of a resort town. Sustainability,, 12(19).

5. Carmichael, B. \& Coën, A. (2020). Real estate as a common risk factor in the financial sector: International evidence. Finance Research Letters, 32, 101172.

6. Fernandez, R., \& Aalbers, M.B. (2016). Financialization and housing: Between globalization and Varieties of Capitalism. Competition\&Change, 20 (2), 71-88.

7. Kowalkowski, C., Gebauer, H., \& Oliva, R. (2017). Service growth in product firms: past, present, and future, Industrial Marketing Management, 60, 82-88.

8. Li, Ya., Zhu, D., Zhao, J., Zheng, X., \& Zhang, L. (2020). Effect of the housing purchase restriction policy on the Real Estate Market: Evidence from a typical suburb of Beijing, China. Land Use Policy. 94, 104528.

9. Liu, Ch., Zheng, Y., Zhao, Q., \& Wang, Ch. (2020). Financial stability and real estate price fluctuation in China, Physica A: Statistical Mechanics and its Applications, 540, 122980.

10. Martín-Peña, M., Sánchez-López, J. \& Díaz-Garrido, E. (2019). Servitization and digitalization in manufacturing: the influence on firm performance. Journal of Business \& Industrial Marketing, 35(3), 564-574.

11. Nishibe, M. (2015). Globalization: Evolution of capitalist market economy through "Internalization of the Market". Evolutionary and Institutional Economics Review, 12 (1), 31-60.

12. Plotnikov, V., \& Pirogova, O. (2018). Key Competencies as an Enterprise Value Management Tool, IBIMA, 1716-1721.

13. Pirogova, O., E., Gorin, \& V., Plotnikov. (2019). The algorithms for the environmental finance based on adjusted present value models. E3S Web of Conferences, Vol. 91, 08021

14. Pirogova, O., Plotnikov V., \& Popovic, Z. (2020). The Multi-level Model of the Service Enterprises Human Capital Value. (Eds.): TransSiberia 2019, AISC 1116, 738-747.

15. Rušćáková, A. (2015). The European Sovereign Debt Crisis: The Result of the Financial Globalisation and of the System Failures of Global Economic and Political Order. Globalization and its socio-economic consequences, 15th International scientific conference proceedings. Rajecke Teplice, Slovak Republic, 617-626.

16. Salisu, A.A., Raheem, I.D., \& Ndako, U.B. (2020). The inflation hedging properties of gold, stocks and real estate: A comparative analysis. Resources Policy, 66, 101605.

17. Skribans, V., Jurušs, M., Demianchuk, M., Maslii, N. \& Pastory, D. (2020). Real estate announcements monitoring dataset for Latvia 2018. Data in Brief. 28, 105064.

18. Vertakova, Y. \& Plotnikov, V. (2016). Innovative and industrial development: specifics of interrelation. Economic Annals-XXI, 156 (1-2), pp. 37-40. 
19. Volkova, J., Bykowa, E., Hełdak, M., Przybyła, K., \& Pawlak, S. (2021). Territorial extrapolation of basic data as a solution of the problem of its deficiency during mass appraisal. Land, 10(7).

20. Yoshida, J. (2020). The economic depreciation of real estate: Cross-sectional variations and their return implications. Pacific-Basin Finance Journal. 61, 101290. 